A. Dmytryk, PhD (Law), Associate Prof.,

O. llyushyk, PhD (Law), Associate Prof.

Lviv State University of Internal Affairs, Lviv, Ukraine

\title{
A SOCIAL FUNCTION IN THE SYSTEM OF STATE FUNCTIONS
}

The article deals with the social function in the system of functions of the state, namely the definition of this concept. In state functioning there is purposeful influence on various spheres of life, social processes and connections. In performing certain functions, the state affects social processes, their dynamics and directions through reforms, transformations, legal regulation of social relations. The implementation of social functions stabilizes the development of the society. The article provides an in-depth analysis of the definitions of the state social functions and provides its relevant concept. It can be argued that the definition of social functions of the state depends on a number of factors, namely legal, political, ideological, informational, etc. It is established that in the theory of the state and law much attention is paid to the study of the social functions of the state. It is determined that the social function of the state, as a dynamic one and inherent in a particular stage of development of the state determines the main activities of the state, expressing its essence and social purpose, aimed at implementing the goals and objectives. The Constitution of Ukraine, along with other tasks, sets the goal of forming a welfare state. The changes that have taken place as a result of the implementation of the Association Agreement between Ukraine, on the one hand, and the European Union, the European Atomic Energy Community and their Member States, on the other hand, have radically changed the socio-political and socio-economic situation in the society, as well as the ideas on the purpose, priorities and methods of realization of the social function of the state. The social function of the state is one of the main activities carried out in the social sphere of public relations to provide citizens with a decent standard of living, resolve social contradictions and realize the agreed interests of citizens, based on socially recognized and legally established social standards. The purpose of this article is to study the social function of the state. Despite the significant number of scientific papers devoted to the study of issues, the harmonisation of national legislation to the requirements of the European Union initiates research on the social function of the state in the context of dynamic socio-economic changes.

Keywords: a state, a function, a social function, the objectives of the state, classification, stability, a social purpose of the state.

Bulletin of Taras Shevchenko National University of Kyiv.

Legal Studies, 2020; 2 (113): 12-18

УДК: 349.6

DOI: https:doi.org/10.17721/1728-2195/2020/2.113-3
ISSN 1728-2195

(C) Taras Shevchenko National University of Kyiv,

Publishing center "Kyiv University", 2020

Т. Коваленко, д-р юрид. наук, доц., проф. ORCID ID: 0000-0002-7103-6209

Київський національний університет імені Тараса Шевченка, Київ, Україна

\section{АДАПТАЦІЯ УКРАЇНСЬКОГО ЗАКОНОДАВСТВА У СФЕРІ ЗАПОБІГАННЯ ЗМІНАМ КЛІМАТУ ДO ACQUIS COMMUNAUTAIRE ЄBPOПЕЙСЬКОГО СОЮзУ}

\begin{abstract}
3'ясовано сучасний стан виконання Угоди про асоціацію між Україною, з однієї сторони, та Європейським Союзом, Європейським співтовариством 3 атомної енергї та їхніми державами-членами, 3 іншої сторони, від 27 червня 2014 року в частині зведення українського законодавства у сфері зміни клімату та захисту озонового шару до вимог правових актів ЄC, перелічених у додатку XXX до глави 6 "Навколишнє середовище" зазначеної Угоди. Установлено, що, починаючи з часу ратифікації Угоди про асоціацію, в Україні було прийнято низку правових актів програмного характеру з метою їі виконання в частині запобігання змінам клімату та захисту озонового шару. Зроблено висновок, що із незначним відставанням Україна загалом виконала свої зобов'язання щодо адаптації національного законодавства до законодавства ЄС у частині створення системи моніторингу, звітності, здійснення перевірок викидів парникових газів, а також у частині імплементації приписів Регламенту (ЄС) № 2037/2000 про речовини, що руйнують озоновий шар, і положення Регламенту (ЄC) № 842/2006 Європейського Парламенту та Ради про деякі фрторовані парникові гази. Водночас, незважаючи на закінчення терміну зведення національного законодавства відповідно до вимог Директиви № 2003/87/ЄС про встановлення схеми торгівлі викидами парникових газів у рамках Співтовариства та внесення змін і доповнень до Директиви № 96/61/ЄС зі змінами і доповненнями, внесеними Директивою № 2004/101/ЄС, в Україні не прийняті нормативно-правові акти, необхідні для запровадження внутрішньої схеми торгівлі квотами на викиди парникових газів та інших ринкових і неринкових інструментів скорочення викидів парникових газів відповідно до зобов'язань України в рамках Угоди про асоціацію. Актуальною залишається потреба внесення змін і доповнень до Положення про Міжвідомчу комісію із забезпечення виконання Рамкової конвенції ООН про зміну клімату, затвердженого постановою Кабінету Міністрів України від 14 квітня 1999 року № 583, у частині розширення їі завдань відповідно до положень Паризької угоди та положень Угоди про асоціацію.
\end{abstract}

Ключові слова: верифікація викидів парникових газів; звітність викидів парникових газів; моніторине викидів парникових газів; озоноруйнівні речовини; охорона клімату та озонового шару; Угода про асоціацію; фторовані парникові гази.

ВСТУп. Відповідно до ст. 361 Угоди про асоціацію між Україною, з однієї сторони, та Європейським Союзом, Європейським співтовариством 3 атомної енергії і їхніми державами-членами, 3 іншої сторони, від 27 червня 2014 року, яка була ратифікована Законом України від 16 вересня 2014 року та набула чинності 3 1 вересня 2017 року [1] (далі - Угода про асоціацію), співробітництво має на меті збереження, захист, поліпшення і відтворення якості навколишнього середовища, захист громадського здоров'я, розсудливе та раціональне використання природних ресурсів і заохочення заходів на міжнародному рівні, спрямованих на розв'язання регіональних і глобальних проблем навколишнього середовища, inter alia, у таких сфрерах як зміна клімату.

У Законі України "Про Основні засади (стратегію) державної екологічної політики України на період до
2030 року" від 28 лютого 2019 року зазначається, що основними джерелами викидів парникових газів в Україні $€$ промисловість, енергетика і транспорт. Енергоємність ВВП України є однією з найвищих у світі: у 2,5 рази вище, ніж у Польщі, та у 3,3 рази вище, ніж у Німеччині [2].

Наслідки зміни клімату (потепління, зростання кількості та інтенсивності екстремальних погодних явищ) одночасно 3 високим рівнем уразливості окремих верств населення призводять до соціальних і економічних втрат сьогодні та в майбутньому. Відзначається зростання загрози катастрофічних повеней у Карпатах, масштабних пожеж на торфовищах, підтоплення територій, розширення аридної зони південного регіону, підвищення частоти та тривалості посух, висихання річок і водойм Причорномор'я, Приазов'я включно 3 лиманами, перетворення степів південного регіону Ук- 
раїни на пустелі, затоплення прибережних територій i гостра нестача питної води в центральних, південних і східних регіонах держави. Зокрема, літо 2018 року було одним із найспекотніших у столиці України місті Києві за майже 140 років. У 2018 році посуха охопила $25 \%$ України, особливо її південно-східну частину. У центральних областях у вересні зазначалася надзвичайна пожежна небезпека [3]. "Відсутність зими" в Україні 2019/2020 років наочно продемонструвала глобальні зміни клімату та має наслідком критично низький рівень водності в річках, зокрема весняної повені не буде вперше за понад 120 років спостережень за погодою [2].

У юридичній літературі питанням правового регулювання запобігання змінам клімату в Україні та міжнародно-правовому регулюванню у цій сфері приділяли увагу О. Бардіна [5], М. Г. Булгакова [6], І. А. Дубовіч [7], Т. В. Єрмолаєва, Т. В. Коротун [8], С. М. Романко [9; 10] та інші вчені. Над правовими аспектами охорони клімату за законодавством $€ C$ i країн-членів ЄС працювали Н.І. Андрусевич [11], Ю. С. Горбань [12], В. І. Шатоха [13], інші вчені. Окремі аспекти адаптації екологічного законодавства загалом і законодавства у сфері охорони клімату зокрема до acquis communautaire Європейського Союзу (далі ЄС) досліджують М. А. Дейнега [14], О. Івасечко [15], С. Орєхов [16], М. О. Тютюнник [17], Н. Я. Шпарик [18] та ін. Водночас до сьогодні не проведено комплексного аналізу виконання Україною Угоди про асоціацію в частині адаптації національного законодавства у сфері запобігання змінам клімату та охорони озонового шару, що зумовлює актуальність теми цієї статті.

Метою дослідження $€$ з'ясування сучасного стану виконання Угоди про асоціацію в частині зведення українського законодавства у сфері зміни клімату та захисту озонового шару до вимог правових актів $€ С$, перелічених у додатку XXX до глави 6 "Навколишнє середовище" зазначеної Угоди. Об'єктом дослідження є Угода про асоціацію, а також прийняті нормативно-правові акти України та проєкти таких актів, які враховують вимоги правових актів $Є C$, спрямованих на охорону клімату.

ВИКЛАД ОСНОВНОГО МАТЕРІАЛУ. Міжнародноправове регулювання охорони клімату. На початку XXI століття світовою спільнотою визнано, що зміна клімату $є$ однією із основних проблем світового розвитку з потенційно серйозними загрозами для глобальної економіки та міжнародної безпеки внаслідок підвищення прямих і непрямих ризиків, пов'язаних з енергетичною безпекою, забезпеченням продовольством і питною водою, стабільним існуванням екосистем, ризиками для здоров'я і життя людей.

У словниках клімат визначається як багаторічний режим погоди, зумовлений сонячною радіацією, її перетворенням у діяльному шарі земної поверхні та пов'язаною з ними загальною циркуляцією атмосфери й океану і характерний для певної місцевості [19]. В еколого-правовому аспекті К. Прохоренко розглядає клімат як цілісну сукупність (систему) природних умов і процесів, що полягають у безперервній взаємодії, обміні та розподілі енергії між природними об'єктами і підлягають правовій охороні як умова, джерело й ознака безпечного, стабільного та якісного навколишнього природного середовища - інтегрованого об'єкта екологічного права [20, с. 105].

На думку деяких учених, до кінця XXI ст. можна очікувати підвищення глобальної температури поверхні Землі в межах $2-2,5^{\circ} \mathrm{C}$ порівняно з доіндустріальним періодом. Такі зміни клімату можуть призвести до екологічної катастрофи. Учений-радник у Німеччині та Ватикані Дж. Шеллнхубер зазначає, що підвищення температури поверхні Землі на $1,5^{\circ} \mathrm{C}$ - це межа, після якої існує реальна небезпека серйозних наслідків для клімату на Землі [21].

Основні підходи до розв'язання зазначеної проблеми закріплені у Рамковій конвенції Організації Об'єднаних Націй про зміну клімату від 9 травня 1992 року. Кіотським протоколом до Рамкової конвенції Організації Об'єднаних Націй про зміну клімату від 11 грудня 1997 року, який Україна ратифрікувала у 2004 році [22], визначено кількісні цілі зі скорочення викидів парникових газів на період до 2020 року для країн розвинених і з перехідною економікою, до яких належить Україна. У грудні 2015 року в місті Парижі була прийнята нова глобальна кліматична Паризька угода до Рамкової конвенції Організації Об'єднаних Націй про зміну клімату, ратифікована Законом України "Про ратифікацію Паризької угоди" від 14 липня 2016 року [23]. Відповідно до положень Паризької угоди Україна як сторона угоди зобов'язана зробити свій національно визначений внесок для досягнення цілей сталого низьковуглецевого розвитку всіх галузей економіки та підвищення здатності адаптуватися до несприятливих наслідків зміни клімату, зокрема шляхом скорочення обсягу викидів парникових газів.

Правове регулювання охорони клімату в $\epsilon$. Одним із лідерів у боротьбі зі змінами клімату у світі $€$ Європейський Союз. Як зазначає Ю. С. Горбань, на цьому шляху ЄС поставив амбіційні цілі, прийняв широке коло теоретичних та законодавчих документів, а також розробив досить ефективні інструменти як на регіональному, так і на державному рівні для своїх державчленів. Активна боротьба зі змінами клімату як у межах $\epsilon C$, так і на міжнародному рівні, $€$ пріоритетним питанням порядку денного ЄС [24].

Як показує аналіз acquis communautaire Європейського Союзу, політика ЄС у сфрері запобігання змінам клімату здійснюється у двох основних напрямах: зменшення викидів парникових газів і адаптація до наслідків зміни клімату. У літературі зазначається, що ця політика зосереджена на таких цілях: 1) більш ефективне споживання енергії; 2) створення більш чистих і збалансованих моделей транспортних засобів і відповідної інфрраструктури; 3) відповідальна діяльність бізнесу; 4) забезпечення екологічного планування землекористування та сільського господарства; 5) створення умов, що сприяють дослідженню та інноваціям [24].

3 метою зменшення викидів парникових газів та адаптації до наслідків зміни клімату у ЄС було прийнято низку важливих документів, серед яких варто назвати: комюніке "Виграємо битву щодо глобальної зміни клімату" 2005 року, Зелену книгу "Адаптація до зміни клімату у Європі - варіанти дій ЄС" 2007 року, Білу книгу 2009 року, у якій наголошується, що адаптація до зміни клімату має бути складовою загальноєвропейської стратегії адаптації.

Також варто зазначити, що у ЄС було розроблено пакет програмних документів до 2020 року у сфері зміни клімату та енергетики, окреслено рамки для відновлювальної політики, орієнтованої на досягнення результатів до 2030 року, і погоджено Дорожню карту дій до 2050 року. Перелічені документи спрямовані на виконання прийнятих ЄС зобов'язань за Кіотським протоколом стосовно скорочення викидів парникових газів на своїй території до $8 \%$.

Приписи Угоди про асоціацію в частині охорони клімату. У додатку XXX до глави 6 "Навколишнє середовище" Угоди про асоціацію передбачається наближення українського законодавства до законо- 
давства ЄС у сфері зміни клімату та захисту озонового шару в такий спосіб.

1) Протягом двох років з дати набуття чинності Угодою національне законодавства має бути зведено до вимог Директиви № 2003/87/€С про встановлення схеми торгівлі викидами парникових газів у рамках Співтовариства та внесення змін і доповнень до Директиви № 96/61/€С зі змінами і доповненнями, внесеними Директивою № 2004/101/€С, зокрема в частині:

- прийняття національного законодавства та визначення уповноваженого органу (органів);

- установлення системи визначення відповідних споруд/установок і визначення парникових газів (додатки I та II);

- розроблення національного плану розподілу квот між заводами/комплексами (ст. 9);

- запровадження дозвільної системи на викиди парникових газів і на квоти, що продаватимуться на національному рівні між заводами/промисловими комплексами в Україні (ст. 4, 11-13);

- створення системи моніторингу, звітності, здійснення перевірок і належного впровадження, а також процедури консультацій із громадськістю (ст. 9, 14-17, 19, 21).

2) Протягом двох років з дати набуття чинності Угодою національне законодавство має бути зведено до вимог Регламенту (ЄС) № 842/2006 про певні фрторовані парникові гази, зокрема в частині:

- прийняття національного законодавства та визначення уповноваженого органу (органів);

- установлення/прийняття національних освітніх і атестаційних вимог для відповідного персоналу та компаній (ст. 5);

- запровадження систем звітності для отримання даних про викиди з відповідних секторів (ст. 6);

- створення системи належного впровадження (ст. 13).

3) Протягом двох років з дати набуття чинності Угодою національне законодавство має бути зведено до вимог Регламенту (ЄС) № 2037/2000 про субстанції, що руйнують озоновий шар, зі змінами та доповненнями, внесеними регламентами (ЄС) № 2038/2000, (ЄC) 2039/2000, (EC) 1804/2003, (EC) 2077/2004, (EC) 29/2006, (ЄC) 1366/2006, (ЄC) 1784/2006, (ЄC) 1791/2006 та (ЄC) 2007/899 і рішеннями № 2003/160/€С, 2004/232/€С та 2007/54/ЄС, зокрема в частині:

- прийняття національного законодавства та визначення уповноваженого органу (органів);

- установлення заборон на підконтрольні речовини, включаючи припинення використання сирих гідрохлорофлоровуглеводнів до 2010 року та всіх гідрохлорофрлоровуглеводнів до 2020 року (ст. 4, 5);

- установлення кількісної межі використання броміду метилу для карантину та контролю вантажу перед відправкою на рівні середнього використання 1996, 1997 та 1998 років (ст. 4);

- поетапна ліквідація поставок на ринок (продаж) сирих гідрохлорофлоровуглеводнів до 2015 року (ст. 4);

- визначення зобов'язань щодо відновлення, переробки, регенерації та знищення використаних підконтрольних субстанцій (ст. 16);

- установлення процедур моніторингу та перевірок витоків підконтрольних субстанцій (ст. 17).

Виконання Україною Угоди про асоціацію в частині охорони клімату. Починаючи з часу ратифрікації Угоди про асоціацію в Україні було прийнято низку правових актів програмного характеру з метою її виконання в частині запобігання змінам клімату та захисту озонового шару. Розпорядженням Кабінету Міністрів України від 17 вересня 2014 р. № 847-р "Про імплементацію Угоди про асоціацію між Україною, з однієї сторо- ни, та Європейським Союзом, Європейським Співтовариством з атомної енергії і їхніми державами-членами, з іншої сторони" стосовно розвитку та імплементації політики з питань зміни клімату було передбачено протягом 2017-2019 років розроблення стратегій низьковуглецевого розвитку й адаптації до зміни клімату на період до 2030 року.

У 2015 році Міністерством екології та природних ресурсів України було підготовлено Національну стратегію наближення (апроксимації) законодавства України до права Європейського Союзу у сфері охорони довкілля, згідно з якою зміна клімату та захист озонового шару визначено одними із основних напрямів наближення законодавства України до законодавства ЄС у сфрері навколишнього середовища [25].

Надалі в Україні були прийняті також інші нормативні акти програмного характеру, спрямовані на виконання зобов'язань України згідно з Угодою про асоціацію в частині адаптації національного законодавства до вимог $€ C$ у сфері запобігання змінам клімату. Розпорядженням Кабінету Міністрів України від 7 грудня 2016 р. № 932-р була схвалена Концепція реалізації державної політики у сфері зміни клімату на період до 2030 року, якою передбачено, зокрема, зміцнення інституційної спроможності щодо формування і забезпечення реалізації державної політики у сфері зміни клімату; запобігання зміні клімату через скорочення антропогенних викидів і збільшення абсорбції парникових газів та забезпечення поступового переходу до низьковуглецевого розвитку держави; адаптація до зміни клімату, підвищення опірності та зниження ризиків, пов'язаних зі зміною клімату.

Планом заходів щодо виконання згаданої вище Концепції реалізації державної політики у сфері зміни клімату на період до 2030 року, затвердженим розпорядженням Кабінету Міністрів України від 6 грудня 2017 р. № 878-р, було передбачено:

- розроблення та внесення на розгляд Кабінету Мiністрів України у 2018 році проєктів законів України щодо запровадження систем моніторингу, звітності та верифрікації викидів парникових газів і торгівлі квотами на викиди парникових газів;

- розроблення та внесення у 2018 році на розгляд Кабінету Міністрів України проєктів актів про внесення змін до Положення про Міжвідомчу комісію із забезпечення виконання Рамкової конвенції ООН про зміну клімату, затвердженого Постановою Кабінету Міністрів України від 14 квітня 1999 р. № 583 у частині розширення ії̈ завдань відповідно до положень Паризької угоди та положень Угоди про асоціацію між Україною та Європейським Союзом, Європейським співтовариством з атомної енергії і їхніми державами-членами, пов'язаних зі зміною клімату; схвалення Стратегії низьковуглецевого розвитку України на період до 2030 року; затвердження порядку здійснення моніторингу та звітності викидів парникових газів; затвердження порядку здійснення верифрікації викидів парникових газів; затвердження порядку підготовки Національного плану розподілу квот між установками; затвердження порядку функціонування дозвільної системи на викиди парникових газів; затвердження комплексного Національного плану з енергетики та зміни клімату на 2021-2030 роки.

У 2017 році Розпорядженням Кабінету Міністрів України від 18 серпня 2017 р. № 605-р було схвалено Енергетичну стратегію України на період до 2035 року "Безпека, енергоефективність, конкурентоспроможність". Відповідно до Розпорядження Кабінету Міністрів України від 6 червня 2018 р. № 497-р було затверджено План заходів з реалізації етапу "Реформування енерге- 
тичного сектору (до 2020 року)" Енергетичної стратегії України, згідно з яким, зокрема, передбачалося розроблення та подання Кабінетові Міністрів України проєкту Стратегії низьковуглецевого розвитку України на період до 2030 року (жовтень 2018 року); розроблення та прийняття нормативно-правових актів, необхідних для запровадження в Україні внутрішньої схеми торгівлі квотами на викиди парникових газів та інших ринкових і неринкових інструментів скорочення викидів парникових газів відповідно до зобов'язань України в рамках Угоди про асоціацію (2018 рік); стимулювання запровадження на об'єктах паливно-енергетичного комплексу системи екологічного менеджменту й аудиту відповідно до міжнародних стандартів (2019 рік).

Необхідно зазначити, що у 2018 році Стратегія низьковуглецевого розвитку України до 2050 року була розроблена Міністерством екології та природних ресурсів України (із 2019 року - Міністерство енергетики та захисту довкілля України). Зазначена Стратегія містить національне бачення відокремлення подальшого економічного зростання та соціального розвитку держави від збільшення обсягу викидів парникових газів. Наявність зазначеної Стратегії $€$ підставою для розроблення й упровадження економічних інструментів підтримки переходу України до низьковуглецевого розвитку, залучення інноваційних технологій і міжнародних фрінансових ресурсів. 30 липня 2018 року Стратегію низьковуглецевого розвитку України року було розміщено на сайті Секретаріату Рамкової Конвенції ООН про зміну клімату [26]. Таким чином, Україна виконала свої міжнародні зобов'язання та увійшла до десятки країн-лідерів кліматичного процесу, що першими опублікували свої Стратегії низьковуглецевого розвитку [27].

У листопаді 2019 року в Україні було проведено парламентські слухання на тему "Пріоритети екологічної політики Верховної Ради України на наступні п'ять років" [28], за наслідками яких було рекомендовано Кабінету Міністрів України прискорити спільно з центральними органами виконавчої влади розроблення i внесення на розгляд Верховної Ради України законопроєктів щодо виконання міжнародних зобов'язань, імплементації законодавства ЄС про зміну клімату та захист озонового шару.

У грудні 2019 року було прийнято Закон України "Про засади моніторингу, звітності та верифрікації викидів парникових газів", який буде введений в дію 3 1 січня 2021 року. Закон спрямований на виконання зобов'язань України за міжнародними договорами, згода на обов'язковість яких надана Верховною Радою України, зокрема Угодою про асоціацію, а також на виконання вимог Рамкової конвенції ООН про зміну клімату та Паризької угоди.

Відповідно до зазначеного вище Закону моніторинг (збирання, обробка, аналіз і зберігання даних) здійснюється оператором щодо викидів парникових газів: двоокису вуглецю $\left(\mathrm{CO}_{2}\right)$, метану $\left(\mathrm{CH}_{4}\right)$, закису азоту $\left(\mathrm{N}_{2} \mathrm{O}\right)$, гідрофторвуглеців (ГФВ), перфторвуглеців (ПФВ), гексафрториду сірки $\left(\mathrm{SF}_{6}\right)$ та інших газоподібних складових атмосфрери, які поглинають і випромінюють інфрачервоне випромінювання, у результаті провадження ним видів діяльності на установці. Оператором визнається юридична або фрізична особа-підприємець, яка здійснює технічну експлуатацію установки (стаціонарного технічного об'єкта, на якому оператор провадить один або більше видів діяльності, а також іншу діяльність, яка має безпосередній технологічний зв'язок із видами діяльності, що провадяться на такому об'єкті, і може впливати на викиди парникових газів), що перебуває в ії власності або користуванні. За результатами монітори- нгу розробляється звіт оператора, який підлягає верифікації, що полягає у перевірці звіту оператора, підготовці та видачі верифікатором за результатами такої перевірки верифікаційного звіту.

Таким чином, із незначним відставанням Україна виконала зобов'язання щодо адаптації національного законодавства до законодавства ЄС у частині створення системи моніторингу, звітності, здійснення перевірок викидів парникових газів. Відповідні новели національного законодавства набудуть чинності 31 січня 2021 року. Водночас необхідним $\epsilon$ розроблення та прийняття підзаконних нормативно-правових актів для забезпечення ефективності приписів Закону України "Про засади моніторингу, звітності та верифікації викидів парникових газів" від 12 грудня 2019 року, оскільки станом на 1 квітня 2020 року жодного нормативноправового акта в його розвиток не прийнято.

Наприкінці 2019 року Україна прийняла Закон "Про регулювання господарської діяльності із озоноруйнівними речовинами та фторованими парниковими газами" від 12 грудня 2019 року, уведення в дію якого відбудеться 27 червня 2020 року. Зазначений Закон регулює відносини щодо виробництва, імпорту, експорту, зберігання, використання, розміщення на ринку та поводження з озоноруйнівними речовинами, фтторованими парниковими газами, товарами й обладнанням, які їх містять або використовують, що впливає на озоновий шар і на рівень глобального потепління. У ньому, зокрема, визначено повноваження центральних органів виконавчої влади; установлено основні вимоги до суб'єктів господарювання; урегульовано процедуру виведення з обігу контрольованих речовин і товарів, що їх містять; закріплено вимоги щодо сертифікації персоналу та відповідного маркування обладнання; визначено порядки імпорту, експорту контрольованих речовин і товарів, що їх місять, а також поводження з відходами, що містять ці речовини.

Провадити операції (імпорт, експорт, розміщення на ринку, зберігання, використання або поводження) з контрольованими речовинами (озоноруйнівними речовинами та/або фрторованими парниковими газами) та/або товарами й обладнанням мають право лише фізичні особи-підприємці або юридичні особи, які набули статусу оператора контрольованих речовин шляхом внесення до Реєстру. Виробництво контрольованих речовин в Україні заборонено. Оператори контрольованих речовин зобов'язані забезпечувати навчання та підтвердження кваліфікації персоналу. Після закінчення навчання за результатами складання іспиту особа отримує кваліфікаційний документ (сертифікат) про підтвердження результатів навчання.

Зазначеним вище Законом імплементовані приписи Регламенту (ЄC) № 2037/2000 про речовини, що руйнують озоновий шар, і положення Регламенту (ЄС) № 842/2006 Європейського Парламенту та Ради про деякі фрторовані парникові гази. Відповідно до додатку XXX до глави 6 "Навколишнє середовище" Угоди про асоціацію передбачено встановлення заборони на озоноруйнівні речовини, включаючи припинення використання сирих гідрохлорфторвуглеців до 2010 року і поетапну ліквідацію поставок на ринок (продажу) сирих гідрохлорфторвуглеців до 2015 року. Відповідно до міжнародних зобов'язань, узятих Україною після ратифікації Монреальського протоколу, на підставі пунктів 5 та 6 статті 2F Поправки до Монреальського протоколу, ратифікованої Законом України від 2 листопада 2000 року, Україна зобов'язалась заборонити споживання озоноруйнівних речовин групи I із додатка C до 1 січня 2020 року, за винятком споживання, обмеженого 
обслуговуванням холодильного обладнання й обладнання для кондиціювання повітря, у період із 2020 по 2030 рік за умов, визначених цим протоколом. На виконання зазначених міжнародних зобов'язань Законом України "Про регулювання господарської діяльності із озоноруйнівними речовинами та фторованими парниковими газами" передбачено, що із дня набуття ним чинності імпорт і розміщення на ринку товарів та обладнання, що містять або працюють із використанням озоноруйнівних речовин, заборонено. 31 січня 2021 року буде заборонено також розміщення на ринку первинних озоноруйнівних речовин.

Незважаючи на зазначені позитивні тенденції адаптації законодавства України до законодавства ЄС у частині запобігання змінам клімату, вимоги Угоди про асоціацію виконані не повністю. Зокрема, незважаючи на закінчення терміну зведення національного законодавства відповідно до вимог Директиви № 2003/87/€С про встановлення схеми торгівлі викидами парникових газів у рамках Співтовариства, в Україні не прийняті нормативно-правові акти, необхідні для запровадження внутрішньої схеми торгівлі квотами на викиди парникових газів та інших ринкових і неринкових інструментів скорочення викидів парникових газів відповідно до зобов'язань України в рамках Угоди про асоціацію. У юридичній літературі цілком справедливо С. М. Романко зазначає, що "...формування національного законодавства у сорері протидії зміні клімату та скороченню викидів парникових газів відбувається повільними темпами та зі встановленням недостатньо амбітних цілей. ... Зокрема, важливими проблемами залишаються відсутність базових програмних документів для скорочення викидів парникових газів і їх адаптації" [10, с. 125].

3 метою виконання Україною Угоди про асоціацію в частині охорони клімату необхідним залишається також внесення змін і доповнень до Положення про Міжвідомчу комісію із забезпечення виконання Рамкової конвенції ООН про зміну клімату, затвердженого постановою Кабінету Міністрів України від 14 квітня 1999 року № 583, у частині розширення ії̈ завдань відповідно до приписів Паризької угоди та Угоди про асоціацію. Постановою Кабінету Міністрів України від 24 січня 2020 р. № 33 було утворено міжвідомчу робочу групу з питань координації подолання наслідків зміни клімату в рамках ініціативи Європейської Комісії "Європейська зелена угода". Проте така міжвідомча група є тимчасовим консультативно-дорадчим органом Кабінету Міністрів України.

\section{ВИСНОВКИ}

1) Із незначним відставанням Україна в цілому виконала свої зобов'язання щодо адаптації національного законодавства до законодавства $€ С$ у частині створення системи моніторингу, звітності, здійснення перевірок викидів парникових газів. У грудні 2019 року було прийнято Закон України "Про засади моніторингу, звітності та верифікації викидів парникових газів", який набуде чинності 31 січня 2021 року. Водночас необхідним $€$ розроблення та прийняття підзаконних нормативно-правових актів для забезпечення ефективності приписів згаданого Закону, оскільки станом на 1 квітня 2020 року жодного нормативно-правового акта в його розвиток не прийнято.

2) Україна також загалом виконала свої зобов'язання в частині імплементації приписів Регламенту (ЄС) № 2037/2000 про речовини, що руйнують озоновий шар, і положення Регламенту (ЄС) № 842/2006 Європейського Парламенту та Ради про деякі фрторовані парникові гази, оскільки прийняла Закон "Про регулювання господарської діяльності з озоноруйнівними ре- човинами та фторованими парниковими газами" від 12 грудня 2019 року, набуття чинності яким відбудеться 27 червня 2020 року.

3) Незважаючи на закінчення терміну зведення національного законодавства відповідно до вимог Директиви № 2003/87/€С про встановлення схеми торгівлі викидами парникових газів у рамках Співтовариства та внесення змін і доповнень до Директиви № 96/61/ЄС зі змінами і доповненнями, внесеними Директивою № 2004/101/€С, в Україні не прийняті нормативноправові акти, необхідні для запровадження внутрішньої схеми торгівлі квотами на викиди парникових газів та інших ринкових і неринкових інструментів скорочення викидів парникових газів відповідно до зобов'язань України в рамках Угоди про асоціацію.

4) Актуальною залишається потреба внесення змін і доповнень до Положення про Міжвідомчу комісію із забезпечення виконання Рамкової конвенції ООН про зміну клімату, затвердженого постановою Кабінету Міністрів України від 14 квітня 1999 року № 583, у частині розширення ії̈ завдань відповідно до приписів Паризької угоди та Угоди про асоціацію.

\section{Список використаних джерел:}

1. Лист Міністерства закордонних справ України "Щодо набрання чинності Угодою" від 20 липня 2017 року № 72/14-612/1-1713. URL: https://zakon.rada.gov.ua/rada/show/v1713321-17 (дата звернення: 15.04.2020).

2. Солонина Є. Зими більше не буде: як вплинуть на Україну та українців глобальні зміни клімату. URL: https://www.radiosvoboda.org/ a/30461594.html (дата звернення: 27.03.2020).

3. Негативні наслідки зміни клімату стають все помітнішими BMO. URL: https://ecoaction.org.ua/nehatyvni-naslidky-zminy-klimatustaiut-pomitnishymy.html (дата звернення: 12.04.2020).

4. Бардіна О. Роль міжнародних інституцій у регулюванні змін клімату. Вісник НТУУ "КПІ". Політологія. Соціологія. Право. 2013. Вип. 3. C. $138-143$.

5. Бардіна О. Міжнародне нормативне забезпечення вирішення проблем зміни клімату. Наукові записки Iнституту законодавства Верховної Ради України. 2013. № 5. С. 131-137.

6. Булгакова М. Г. Участь України у міжнародних переговорах з питань зміни клімату: економіко-правові та еколого-політичні аспекти. Вісник Національного університету водного господарства та природокористування. Серія "Економіка". 2012. Вип. 1. С. 37-43

7. Дубовіч І. А., Булгакова М. Г. Теоретико-методологічні та практичні еколого-економічні й правові засади розв'язання глобальних проблем зі зміни кпімату. Науковий вісник Ужгородського національного університету. Серія: Міжнародні економічні відносини та світове господарство. 2016. Вип. 8. Ч. 1. С. 67-70

8. Єрмолаєва Т. В., Коротун Т. В. Реалізація Україною міжнародних зобов'язань у сфері запобігання змінам клімату. Молодий вчений. 2018. № 10. C. $236-240$.

9. Романко С. Еколого-правова політика України у сфері зміни клімату. Підприємництво, господарство і право. 2019. № 9. С. 88-94.

10. Романко С. Законодавство України у сфері скорочення викидів парникових газів після ратифікації Паризької угоди. Visegrad Journal on Human Rights. 2018. V. 1. Р. 122-127.

11. Андрусевич Н. Правове регулювання $€ С$ в галузі попередження зміни клімату. Вісник екологічної адвокатури. 2004. № 26. С. 3-8.

12. Горбань Ю. С. Імплементаційні інструменти ЄС у сфері зміни клімату: досвід Німеччини. Державне управління: удосконалення та розвиток. 2014. № 10. URL: http://www.dy.nayka.com.ua/?op=1\&z=770 (дата звернення: 15.04.2020).

13. Шатоха В.І.Лідерство Європейського Союзу у запобіганні зміни клімату: Монографія. Дніпро: Акцент ПП, 2017. 144 с.

14. Дейнега М. А. Інтеграція природоресурсного законодавства України до законодавства Європейського Союзу у сфері зміни клімату. Право. Людина. Довкілля. 2019. № 3. Том. 10. С. 66-75.

15. Івасечко О. Співпраця України та Європейського Союзу в галузі охорони довкілля. Українська національна ідея: реалії та перспективи розвитку. 2012. Вип. 24. С. 73-78.

16. Орєхов С. Адаптація права України до права ЄС у ссрері охорони довкілля в рамках Угоди про асоціацію. Підприємництво, господарство і право. 2019. № 2. С. 80-83.

17. Тютюнник М. О. Адаптація екологічного законодавства України до законодавства Єропейського Союзу. The Journal of Eastern European Law / Журнал східноєвропейського права. 2019. № 63. C. 358-364.

18. Шпарик Н. Я. Адаптація екологічного законодавства України до стандартів Європейського Союзу. Науковий вісник Ужгородського національного університету. Серія Право. 2015. Вип. 33. Том 1. C. $212-217$ 
19. Кліматологія. Терміни та визначення основних понять. ДСТУ 3992 - 2000 - K: Держспоживстандарт України 2000 URL http://metrology.com.ua/download/dstu-gost-gost-r/60-dstu/476-dstu-39922000 (дата звернення: 09.04.2020)

20. Прохоренко К. Теоретичні аспекти поняття "клімат" в екологоправовому регулюванні. Вісник Київського національного університету ім. Тараса Шевченка. Юрид. науки. 2011. Вип. 86. С. 104-106.

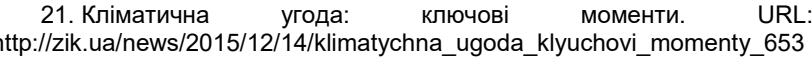
978 (дата звернення: 15.04.2020).

22. Закон України "Про ратифрікацію Кіотського протоколу до Рамкової конвенції Організації Об'єднаних Націй про зміну клімату" від 04.02.2004. Офріційний вісник України. 2004. № 8. Ст. 466

23. Закон України "Про ратиффікацію Паризької угоди" від 14.07.2016. Відомості Верховної Ради України. 2016. № 35. Ст. 595.

24. Горбань Ю. С. Імплементаційні інструменти ЄС у сфері зміни клімату: досвід Німеччини. Державне управління: удосконалення та розвиток. 2014. № 10. URL: http://www.dy.nayka.com.ua/?op=1\&z=770 (дата звернення: 02.01.2020)

25. Національна стратегія наближення (апроксимації) законодавства України до права Європейського Союзу у сфері охорони довкілля. Київ, 2015. URL: https://menr.gov.ua/files/docs/draft_NAS_FEB2015.pdf (дата звернення: 15.03.2020)

26. Communication of long-term strategies. URL: https://unfccc.int process/the-paris-agreement/long-term-strategies (дата звернення: 11.02.2020).

27. Стратегія низьковуглецевого розвитку України до 2050 року. URL: https://menr.gov.ua/news/31815.html (дата звернення: 15.04.2020).

28. Рекомендації парламентських слухань на тему: "Пріоритети екологічної політики Верховної Ради України на наступні п'ять років", схвалені Постановою Верховної Ради України від 14.01.2020 № 457-ІХ. Голос України. 2020. № 18. 30 січня.

References:

1. Lyst Ministerstva zakordonnykh sprav Ukrainy "Shchodo nabrannia chynnosti Uhodoiu" vid 20 lypnia 2017 roku № 72/14-612/1-1713. URL: https://zakon.rada.gov.ua/rada/show/v1713321-17 (data zvernennia: 15.04.2020) (in Ukrainian).

2. Solonyna Ye. Zymy bilshe ne bude: yak vplynut na Ukrainu ta ukraintsiv hlobalni zminy klimatu [Winters will be gone: how global climate change will affect Ukraine and the Ukrainians]. URL: https://www.radiosvoboda.org/a/30461594.html (data zvernennia: 27.03.2020) (in Ukrainian).

3. Nehatyvni naslidky zminy klimatu staiut vse pomitnishymy - VMO [The negative effects of climate change are becoming more visible - WMO]. URL: https://ecoaction.org.ua/nehatyvni-naslidky-zminy-klimatu-staiutpomitnishymy.html (data zvernennia: 12.04.2020) (in Ukrainian)

4. Bardina O. Rol mizhnarodnykh instytutsii u rehuliuvanni zmin klimatu [The role of international institutions in regulating climate change]. Visnyk NTUU "KPI". Politolohiia. Sotsiolohiia. Pravo. 2013. Vyp. 3 (19). S. 138-143 (in Ukrainian).

5. Bardina O. Mizhnarodne normatyvne zabezpechennia vyrishennia problem zminy klimatu [International regulatory support for climate change]. Naukovi zapysky Instytutu zakonodavstva Verkhovnoi Rady Ukrainy. 2013. № 5. S. 131-137 (in Ukrainian).

6. Bulhakova M. H. Uchast Ukrainy u mizhnarodnykh perehovorakh z pytan zminy klimatu: ekonomiko-pravovi ta ekoloho-politychni aspekty [Ukraine's participation in international negotiations on climate change: economic, legal and environmental-political aspects]. Visnyk Natsionalnoho universytetu vodnoho hospodarstva ta pryrodokorystuvannia. Seriia "Ekonomika". 2012. Vyp. 1. S. 37-43 (in Ukrainian).

7. Dubovich I. A., Bulhakova M. H. Teoretyko-metodolohichni ta praktychni ekoloho-ekonomichni y pravovi zasady rozviazannia hlobalnykh problem zi zminy klimatu [Theoretical, methodological and practical environmental, economic and legal principles of addressing global climate change issues]. Naukovyi visnyk Uzhhorodskoho natsionalnoho universytetu. Seriia: Mizhnarodni ekonomichni vidnosyny ta svitove hospodarstvo. 2016. Vyp. 8. Ch. 1. S. 67-70 (in Ukrainian)

8. Yermolaieva T. V., Korotun T. V. Realizatsiia Ukrainoiu mizhnarodnykh zoboviazan u sferi zapobihannia zminam klimatu [Ukraine's implementation of international commitments in the field of climate change prevention]. Molodyi vchenyi. 2018. № 10. S. 236-240 (in Ukrainian).

9. Romanko S. Ekoloho-pravova polityka Ukrainy u sferi zminy klimat [Ukraine's environmental and legal policy in the field of climate change]. Pidpryiemnytstvo, hospodarstvo i pravo. 2019. № 9. S. 88-94 (in Ukrainian).

10. Romanko S. Zakonodavstvo Ukrainy u sferi skorochennia vykydiv parnykovykh haziv pislia ratyfikatsii Paryzkoi uhody [Legislation of Ukraine in the field of greenhouse gas emission reduction after ratification of the
Paris Agreement]. Visegrad Journal on Human Rights. 2018. V. 1. S. 122127 (in Ukrainian).

11. Andrusevych N. Pravove rehuliuvannia YeS v haluzi poperedzhennia zminy klimatu [EU legal regulation on climate change prevention]. Visnyk ekolohichnoi advokatury. 2004. № 26. S. 3-8 (in Ukrainian).

12. Horban Yu. S. Implementatsiini instrumenty YeS u sferi zminy klimatu: dosvid Nimechchyny [EU Climate Change Implementation Instruments: German Experience]. Derzhavne upravlinnia: udoskonalennia ta rozvytok. 2014. № 10. URL: http://www.dy.nayka.com.ua/?op=1\&z=770 (data zvernennia: 15.04.2020) (in Ukrainian).

13. Shatokha V. I. Liderstvo Yevropeiskoho Soiuzu u zapobihanni zminy klimatu [Leadership of the European Union in preventing climate change]: Monohrafiia. Dnipro: Aktsent PP, 2017. 144 s. (in Ukrainian).

14. Deineha M. A. Intehratsiia pryrodoresursnoho zakonodavstva Ukrainy do zakonodavstva Yevropeiskoho Soiuzu u sferi zminy klimatu [Integration of the natural resources legislation of Ukraine with the legislation of the European Union in the field of climate change]. Pravo. Liudyna. Dovkillia. 2019. № 3, Tom. 10. S. 66-75 (in Ukrainian).

15. Ivasechko O. Spivpratsia Ukrainy ta Yevropeiskoho Soiuzu v haluzi okhorony dovkillia [Cooperation between Ukraine and the European Union in the field of environment]. Ukrainska natsionalna ideia: realii ta perspektyvy rozvytku. 2012. Vyp. 24. S. 73-78 (in Ukrainian)

16. Oriekhov S. Adaptatsiia prava Ukrainy do prava YeS u sferi okhorony dovkillia v ramkakh Uhody pro asotsiatsiiu [Adaptation of Ukraine's right to EU environmental law within the framework of the Association Agreement]. Pidpryiemnytstvo, hospodarstvo i pravo. 2019. № 2. S. 80-83 (in Ukrainian).

17. Tiutiunnyk M. O. Adaptatsiia ekolohichnoho zakonodavstva Ukrainy do zakonodavstva Yeropeiskoho Soiuzu [Adaptation of the environmental legislation of Ukraine to the legislation of the European Union]. The Journal of Eastern European Law / Zhurnal skhidnoievropeiskoho prava. 2019. № 63. S. 358-364 (in Ukrainian).

18. Shparyk N. la. Adaptatsiia ekolohichnoho zakonodavstva Ukrainy do standartiv Yevropeiskoho Soiuzu [Adaptation of the environmental legislation of Ukraine to the standards of the European Union]. Naukovy visnyk Uzhhorodskoho natsionalnoho universytetu. Seriia Pravo. 2015. Vyp. 33. Tom 1. S. 212-217 (in Ukrainian).

19. Klimatolohiia. Terminy ta vyznachennia osnovnykh poniat. DSTU 3992 - 2000. - K.: Derzhspozhyvstandart Ukrainy, 2000. URL: http://metrology.com.ua/download/dstu-gost-gost-r/60-dstu/476-dstu-39922000 (data zvernennia: 09.04.2020) (in Ukrainian).

20. Prokhorenko K. Teoretychni aspekty poniattia "klimat" v ekolohopravovomu rehuliuvanni [Theoretical aspects of the concept of "climate" in environmental regulation]. Visnyk Kyivskoho natsionalnoho universytetu im. Tarasa Shevchenka. Yuryd. nauky. 2011. Vyp. 86. S. 104-106 (in Ukrainian).

21. Klimatychna uhoda: kliuchovi momenty. URL: http://zik.ua/news/ 2015/12/14/klimatychna ugoda klyuchovi momenty 653978 (data zvernennia: 15.04.2020) (in Ukrainian).

22. Zakon Ukrainy "Pro ratyfikatsiiu Kiotskoho protokolu do Ramkovoi konventsii Orhanizatsii Obiednanykh Natsii pro zminu klimatu" vid 04.02.2004. Ofitsiinyi visnyk Ukrainy. 2004. № 8. St. 466 (in Ukrainian).

23. Zakon Ukrainy "Pro ratyfikatsiiu Paryzkoi uhody" vid 14.07.2016. Vidomosti Verkhovnoi Rady Ukrainy. 2016. № 35. St. 595 (in Ukrainian).

24. Horban Yu. S. Implementatsiini instrumenty YeS u sferi zminy klimatu: dosvid Nimechchyny [EU Climate Change Implementation Instruments: German Experience]. Derzhavne upravlinnia: udoskonalennia ta rozvytok. 2014. № 10. URL: http://www.dy.nayka.com.ua/?op=1\&z=770 (data zvernennia: 02.01.2020) (in Ukrainian).

25. Natsionalna stratehiia nablyzhennia (aproksymatsii) zakonodavstva Ukrainy do prava Yevropeiskoho Soiuzu u sferi okhorony dovkillia. - Kyiv, 2015. URL: https://menr.gov.ua/files/docs/draft_NAS_FEB2015.pdf (data zvernennia: 15.03.2020) (in Ukrainian).

26. Communication of long-term strategies. URL: https://unfccc.int/ process/the-paris-agreement/long-term-strategies (the date of request: 11.02.2020) (in English)

27. Stratehiia nyzkovuhletsevoho rozvytku Ukrainy do 2050 roku. URL: https://menr.gov.ua/news/31815.html (data zvernennia: 15.04.2020) (in Ukrainian).

28. Rekomendatsii parlamentskykh slukhan na temu: "Priorytety ekolohichnoi polityky Verkhovnoi Rady Ukrainy na nastupni piat rokiv", skhvaleni Postanovoiu Verkhovnoi Rady Ukrainy vid 14.01.2020 № 457-IX Holos Ukrainy. 2020. № 18. 30 sichnia (in Ukrainian).

Received: $22 / 04 / 2020$ Accepted: $20 / 05 / 2020$

T. Kovalenko, Dr. of Law, Associate Prof., Prof.

Taras Shevchenko National University of Kyiv, Kyiv, Ukraine

\section{THE ADAPTATION OF UKRAINIAN LEGISLATION ON CLIMATE CHANGES TO THE ACQUIS COMMUNAUTAIRE OF THE EUROPEAN UNION}

The article examines the current state of the Association Agreement implementation in terms of national legislation on climate change and the protection of the ozone layer compliance with the requirements of the EU legal acts listed in Annex XXX to Chapter 6 "Environment" of that Agreement. Under the Association Agreement, such harmonization entails the need to bring national legislation into line with Directive № 2003/87/EC establishing a Community greenhouse gas emissions trading scheme by September 1, 2019 and amending Directive № 96/61/EC 
as amended by Directive № 2004/101/EC; Regulation (EC) № 842/2006 on certain fluorinated greenhouse gases; Regulation (EU) № 2037/2000 on substances that deplete the ozone layer, as amended and the amendments made by the Regulation (EU) №№ 2038/2000, (EU) 2039/2000, (EU) 1804/2003, (EU) 2077/2004, (EU) 29/2006, (EU) 1366/2006, (EU) 1784/2006, (EC) 1791/2006 and (EC) 2007/899, and Decisions №№ 2003/160 /EC, 2004/232/EC and 2007/54 /EC.

The analysis of the national legislation shows that Ukraine as a whole fulfilled its obligations to adapt national legislation to the EU legislation in terms of setting up a monitoring system, reporting and verification of greenhouse gas emissions. The Law of Ukraine "On the Basics of Monitoring, Reporting and Verification of Greenhouse Gas Emissions" was adopted on 12 December 2019. The law comes into force on 1 January 2021. At the same time, it is necessary to adopt by-laws to ensure the effectiveness of the provisions of the aforementioned Law, since as of 1 April 2020 no legislative act has been adopted in its development.

Ukraine has also fully fulfilled its obligations to implement the provisions of Regulation (EC) № 2037/2000 on substances that deplete the ozone layer and the provisions of Regulation (EC) № 842/2006 of the European Parliament and of the Council on certain fluorinated greenhouse gases. The Law of Ukraine "On Regulation of Economic Activity with Ozone-Depleting Substances and Fluorinated Greenhouse Gases" was adopted on 12 December 1 2019. The law comes into force on 27 June 2020.

The article proves that the legal acts, necessary to introduce internal greenhouse gas emission allowance trading scheme and other market and non-market greenhouse gas emission reduction instruments of these gases in accordance with Ukraine's obligations under the Association Agreement have not yet been adopted.

Also there is the necessity to make amendments to the Regulation on the Interagency Commission on Implementation of the United Nations Framework Convention on Climate Change, approved by the Cabinet of Ministers of Ukraine Decree № 583 of April 14, 1999, to extend its tasks in accordance with the provisions of the Paris Agreement.

Keywords: the Association Agreement; climate and ozone protection; fluorinated greenhouse gases; monitoring of greenhouse gas emissions; ozone-depleting substances; reporting of greenhouse gas emissions; verification of greenhouse gas emissions.

Bulletin of Taras Shevchenko National University of Kyiv. Legal Studies, 2020; 2 (113): 18-23

УДК: 349.42

DOI: https:doi.org/10.17721/1728-2195/2020/2.113-4
ISSN 1728-2195

(C) Taras Shevchenko National University of Kyiv, Publishing center "Kyiv University", 2020

М. Копиця, асп. ORCID ID: 0000-0002-2534-0103

Київський національний університет імені Тараса Шевченка, Київ, Україна

\section{ДО ПИТАННЯ ПРО ДЕРЖАВНУ ПІДТРИМКУ ТА ПУБЛІЧНЕ АДМІНІСТРУВАННЯ В АГРАРНОМУ ПРАВІ УКРАÏHИ}

Обраний державою курс на євроінтеграцію та подальший вступ Украӥни до Європейського Союзу вимагають реформування національного законодавства і системи органів влади, а також перегляду ролі держави в суспільних відносинах, у тому числі аграрних. У зө'язку з цим виникає необхідність проведення аграрної реформи, основною метою та завданням якої має бути забезпечення діяльності національного товаровиробника, виведення аграрного сектору України на міжнародний рівень, а також зміцнення позицій української продукції на світовому ринку. Однак без належної участі держави досягнення зазначених цілей практично неможливе. Саме тому роль держави в забезпеченні розвитку аграрнопромислового сектору є ключовою. При цьому держава не має втручатися у ведення агробізнесу, а зобов'язана створити лише сприятливе середовище для суб'єктів господарювання. У такому випадку важливим є забезпечення належного публічного адміністрування аграрних правовідносин, що, у свою чергу, породжує необхідність дослідження сутності публічного адміністрування, мети та механізмів його реалізації, а також законодавчої регламентації. Значної уваги потребує дослідження державної підтримки сільського господарства, яка останні роки є основним видом участі держави у сфері АПК. Публічне адміністрування і безпосередньо державна підтримка сільського господарства створюють належні умови для агробізнесу й надають можливість розвитку суб'єктів малого та середнього бізнесу.

У статті досліджено поняття публічного адміністрування та державної підтримки сільського господарства, визначено їхню мету і зміст. Зазначено, що законодавство не містить визначення досліджуваних понять, а лище їхні окремі характеристики. Зроблено порівняльно-правову характеристику публічного адміністрування та державної підтримки, установлено, що це різні правові категорії, однак взаємопов'язані та взаємозалежні.

Ключові слова: публічне адміністрування, державна підтримка, державна допомога, публічна адміністрація, аграрні правовідносини, органи державної влади.

ВСтуп. Актуальність обраної тематики зумовлена тим, що аграрний сектор економіки є основним виробником життєво важливих продуктів харчування і відіграє виняткову роль у забезпеченні продовольчої безпеки та продовольчої незалежності країни. В умовах глобалізації соціально-економічних процесів і міжнародної конкуренції істотно зростають ризики та загрози для сталого розвитку вітчизняного аграрного сектору економіки. У зв'язку з цим ефективна робота сільського господарства можлива лише за активної участі держави. Створення умов для сталого розвитку сільських територій, прискорення темпів зростання обсягів сільськогосподарського виробництва на основі підвищення його конкурентоспроможності має бути пріоритетним напрямом аграрної економічної політики держави. Отже, обов'язковою умовою належного розвитку сільського господарства $€$ публічне адміністрування, у тому числі державна підтримка сільськогосподарських товаровиробників.

У теорії аграрного права значна увага приділяється дослідженню державної підтримки аграрного сектору, яка в більшості випадків розглядається як вид держа- вного управління чи державного регулювання. Однак в умовах євроінтеграції все більшої уваги науковців потребує дослідження таких понять, як публічне адміністрування, публічне управління, роль публічного адміністрування в забезпеченні розвитку сільського господарства, а також порівняльна характеристика державної підтримки та публічного адміністрування в аграрному праві України. Результати дослідження зазначених питань передусім допоможуть установити найкращі механізми участі держави в аграрному секторі економіки задля сталого розвитку сільськогосподарського виробництва.

Метою дослідження є порівняння державної підтримки та публічного адміністрування в аграрному праві України, визначення їхніх спільних і відмінних характеристик, установлення методів здійснення державної підтримки та публічного адміністрування, дослідження досвіду зарубіжних країн щодо державної підтримки та публічного адміністрування сільськогосподарських товаровиробників. 